\title{
ПОНЯТИЕ И ОСОБЕННОСТИ ПРАВОВОГО МЕХАНИЗМА РЕКУЛЬТИВАЦИИ ЗЕМЕЛЬ СЕЛЬСКОХОЗЯЙСТВЕННОГО НАЗНАЧЕНИЯ
}

\begin{abstract}
Аннотация: Предмет исследования: понятие и особенности механизма рекультивации земель сельскохозяйственного назначения.Цель: рассмотреть актуальные вопросы, касающчеся рекультивации земель сельскохозяйственного назначения, мелиорации, особенностей правового закрепления рекультивации земель.Результатьв: анализируется понятие и особенности механизма рекультивации земель сельскохозяйственного назначения, определяются цели рекультивации нарушенных земель сельскохозяйственного назначения, указываются пробель в законодательстве, обосновываются предложения по совершенствованию законодательства, включаюшие в себя конкретные изменения в действующие нормативные правовые акты: Закон РФ «О недрах», Градостроительный кодекс РФ. Методы: анализа, синтеза, дедукции, индукиии, сравнительно-правовой, диалектический, аналогии, конкретизации, структурно-функциональный, системный, исторический, аналогии. Научная новизна: проведено исследование действующего законодательства в области рекультивации земель сельскохозяйственного назначения, внесены предложения по его совершенствованию.Практическая значимость: основные положения и выводы статьи могут быть использованы при дальнейшем совершенствовании земельного законодательства, также в научной деятельности. Выводы: одним из важнейших способов охрань и восстановления качества земель является рекультивация, постоянные изменения в аграрном и земельном законодательстве требуют внесения изменений и в части рекультивации земель сельхоз назначения.
\end{abstract}

Ключевые слова: Рекультивация, мелиорация, земли сельхозназначения, земельное законодательство, недры, правовое регулирование, закон, трелевка, участки, недропользователь.

Abstract: This article examines the relevant issues pertaining to revegetation of agricultural land, melioration, and the legal aspects of land revegetation. The results of the analysis include the peculiarities of the revegetation mechanism, determination of goals of revegetation of disturbed agricultural land, demonstration of gaps in the legislation, and substantiation of the proposal to improve the legislation with specific changes to the current normative legal acts: the law "On the Subsurface", Urban Development Code of the Russian Federation. The scientific novelty consists in the fact that the author examines the current legislation in the area of revegetation of land designated as agricultural, and proposes ways of improving it, which could be used in further development of land legislation and other scientific research on this subject. The author concludes that one of the key ways to protect and restore the quality of the land is revegetation. The constant changes in agricultural and land legislation require changes in the area of revegetation of land of agricultural designation.

Keywords: Revegetation, Melioration, Agricultural land, Land legislation, Subsurface, Legal regulation, Law, Logging, Lots, Land use.

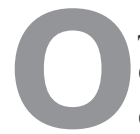

дним из важнейших способов охраны и восстановления качества земель сельскохозяйственного назначения называется рекультивация. В действующем законодательстве предлагается регулирование порядка и условий проведения работ по рекультивации земель сельскохозяйственного назначения, если они нарушены в ходе проведения различных видов хозяйственной деятельности. В соответствии с пп. 6 п. 1 ст. 13 ЗК РФ к числу мероприятий по охране любой категории земель относится работы по их рекультивации. Для того чтобы обеспечить охрану земель сельскохозяйственного назначения, их собственники, пользователи, владельцы и арендаторы должны осу- ществлять мероприятия по рекультивации нарушенных земель сельскохозяйственного назначения.

На сегодняшний день сохраняет силу Постановление Правительства РФ от 23.02.1994 N 140 «О рекультивации земель, снятии, сохранении и рациональном использовании плодородного слоя почвы» [1, ст. 779]. По данному Постановлению самые важные требования к порядку проведения рекультивационных работ для земель сельскохозяйственного назначения состоят в следующем: определение перечня работ, которые связаны с нарушением поверхности почв, не носящего исчерпывающего характера; рекультивационные работы для земель сельскохозяйственного назначения, которые 
DOI: $10.7256 / 1811-9018.2015 .9 .16159$

При цитировании этой статьи сноска на доі обязательна

\section{Право и политика 9 (189) 2015}

должны проводиться в соответствии со специально разработанным для конкретного проекта рекультивации документом, и определение порядка финансирования данных работ.

Приказом Минприроды РФ N 525, Роскомзема N 67 от 22.12.1995 «Об утверждении Основных положений о рекультивации земель, снятии, сохранении и рациональном использовании плодородного слоя почвы» (Зарегистрировано в Минюсте РФ 29.07.1996 N 1136) утверждены основные положения о рекультивации земель, снятии, сохранении и рациональном использовании плодородного слоя почвы [2]. В данном положении определены цели рекультивации нарушенных земель сельскохозяйственного назначения. В соответствии с ним рекультивация земель сельскохозяйственного назначения осуществляется в целях восстановления их в нуждах сельского хозяйства, лесного хозяйства, водного хозяйства, а также целей строительства, рекреации, природной охраны и санитарного оздоровления (п. 3). Определено, что рекультивация для целей сельского хозяйства, лесного хозяйства и других целей, которые требуют восстановления плодородия, осуществляется двумя этапами. Первый носит характер технический, второй - биологический (п. 4). Систематизированы виды деятельности, которые являются причиной нарушение земель сельскохозяйственного назначения (п. 5).

За последние двадцать лет земельное и аграрное законодательство претерпело настолько сильные изменения, что данный нормативный акт во многом перестал соответствовать действующему законодательству. Например, предусмотрено, что основания приведения нарушенных земель сельскохозяйственного назначения в состояние, которое пригодно для дальнейшего использования, а также процедура снятия, хранения и последующего применения плодородного слоя устанавливаются органами, которые предоставляют земельные участки в пользование и которые дают разрешение на осуществление работ, связанных с нарушением почвенного слоя, на основе планов и проектов рекультивации земель, которые получили положительное заключение и одобрение государственной экологической экспертизы (п. 6). Данная норма в целом соответствует положениям законодательства, но только лишь в той части, где даются требования разработки проекта рекультивации. Действующее законодательство не включает требования об определении оснований приведения нарушенных сельскохозяйственных земель в то состояние, которое пригодно для дальнейшего использования, теми органами, которые предоставляют данные участки. В соответствии со ст. 19 Закона РФ от 21.02.1992 N 2395-1 (ред. от 31.12.2014) «О недрах» [3, ст. 823] регулирование вопросов добычи общераспространенных ископаемых собственниками земельных участков, пользователями, владельцами, а также их арендаторами, не предполагает для этого получения какой-либо лицензии. Также не требуется получения разрешения в градостроительном законодательстве и при проведении государственной экологической экспертизы. Приведен перечень работ, затраты на которые относятся к рекультивации земель сельскохозяйственного назначения.

Важно подчеркнуть, что требование о норме снятия плодородного слоя, потенциально плодородных слоев при проектировании и определении целей использования почвы в дальнейшем не подкреплены санитарно-эпидемиологическими требованиями, которые бы определяли возможность использования снятого слоя почвы для рекультивации земель сельскохозяйственного назначения, для использования их в сельскохозяйственных нуждах. На сегодняшний день действует Постановление Главного государственного санитарного врача РФ от 17.04.2003 N 53 (ред. от 25.04.2007) «О введении в действие СанПиН 2.1.7.1287-03» (вместе с «СанПиН 2.1.7.128703. 2.1.7. Почва, очистка населенных мест, бытовые и промышленные отходы, санитарная охрана почвы. Санитарно-эпидемиологические требования к качеству почвы. Санитарно-эпидемиологические правила и нормативы», утв. Главным государственным санитарным врачом РФ 16.04.2003) (Зарегистрировано в Минюсте РФ 05.05.2003 N 4500) [4]. Но СанПиН не регулирует вопросы использования загрязненных почв в целях рекультивации земель сельскохозяйственного назначения.

Общие положения предусматривают, что сроки проведения технического этапа рекультивации должны определяться теми органами, которые предоставили земельный участок и давали разрешение на проведение работ, на основе проектных материалов и планов (п. 9). Данное положение соответствует нормам законодательства в части сроков, которые должны определяться проектной документацией. Необходимо законодательно закрепить момент, когда проведение работ по рекультивации земель сельскохозяйственного назначения считается завершенным. В этой связи важное значение приобретает законодательное определение понятия «рекультивированные земли». Данное определение содержится в Приказе Росстата от 29.12.2012 N 676 «Об утверждении статистического инструментария для организации Федеральной службой по надзору 
в сфере природопользования федерального статистического наблюдения за рекультивацией земель, снятием и использованием плодородного слоя почвы» [5]. В соответствии с п. 7 Приказа рекультивированными считаются земли, приведенные в состояние, пригодное для использования в народном хозяйстве (сельском, лесном, водном и др.) и принятые по актам в соответствии с Положением о порядке приемкипередачи рекультивированных земель.

Как было указано выше, градостроительное законодательство и законодательство о недрах не предусматривает для этого получения разрешения. Процедура осуществления таких работ устанавливается органами исполнительной власти субъектов РФ в соответствии со ст. 19 Закона РФ «О недрах». В соответствии с п. 5 Постановления Правительства РФ от 02.01.2015 N 1 «Об утверждении Положения о государственном земельном надзоре» [6, ст.514] Федеральная служба по надзору в сфере природопользования и ее территориальные органы осуществляют государственный земельный надзор за соблюдением, в частности: обязанностей по рекультивации земель при разработке месторождений полезных ископаемых, включая общераспространенные полезные ископаемые, осуществление строительных, мелиоративных, изыскательских и иных работ, в том числе работ, осуществляемых для внутрихозяйственных или собственных надобностей, а также после завершения строительства, реконструкции и (или) эксплуатации объектов, не связанных с созданием лесной инфраструктуры, сноса объектов лесной инфраструктуры.

Так как отдельные нормы Основных положений не соответствуют законодательству, их применение не решает в полной мере проблему рекультивации земель сельскохозяйственного назначения. Представляется, что необходимо принять новый закон, который бы подробно регулировал порядок рекультивации. Правовое регулирование работ по рекультивации земель сельскохозяйственного назначения зависит от вида деятельности, который влечет нарушение плодородного слоя земель.

П. 2 ст. 46 Федерального закона «Об охране окружающей среды» закрепляет требование, что размещение, проектирование, строительство, реконструкция, ввод в эксплуатацию и эксплуатация объектов нефтегазодобывающих производств, переработка, транспортировка, хранение и реализация нефти, газа и продуктов их переработки должны сопровождаться эффективными мерами по рекультивации нарушенных и загрязненных земель. Диспозиция данной нормы детализировалась в ряде законодательных актах. Например, в соответствии с п. 4 ст. 88 ЗК РФ организациям горнодобывающей и нефтегазовой промышленности предоставляются земельные участки в целях разработки полезных ископаемых только после оформления горного отвода, а также утверждения проекта рекультивации земель. Особо ценные сельскохозяйственные угодья должны предоставляться в соответствии со ст. 79 ЗК РФ только после отработки других угодий, которые расположены в границах горного отвода. Отсюда можно сделать вывод о том, что законодательство предусматривает предоставление земель для разработки полезных ископаемых только после оформления горного отвода, утверждения проекта рекультивации и восстановления ранее отработанных земель. Помимо этого, в соответствии с п.п. 8 п. 1 ст. 7 Федерального закона «О переводе земель или земельных участков из одной категории в другую» перевод сельскохозяйственных угодий и земельных участков в их составе из земель сельскохозяйственного назначения в другую категорию возможен в исключительных случаях, в том числе связанных с добычей полезных ископаемых и только при наличии утвержденного проекта рекультивации.

Более высокую юридическую силу в регулировании предоставления земель для недропользования земель имеет земельное законодательство. Если опираться на ст. 25.1 Закона РФ «О недрах», земельные участки, необходимые для ведения работ, связанных с изучением и иным использованием недр, предоставляются на условиях и в порядке, установленном земельным законодательством. Но, законодательство о недрах иначе регулирует соотношение разработки и утверждения проектов ведения работ, которые связаны с пользованием недрами, и проектов рекультивации земельных участков. Следует отметить, что Закон РФ «О недрах» прямо не предусматривает в качестве обязанности пользователя рекультивировать земли. П.п. 7 ч. 1 ст. 22 Закона РФ «О недрах» закрепил обязанность недропользователя обеспечивать соблюдение стандартов (норм и правил), регламентирующих охрану земель от влияния работ, которые связаны с пользованием недрами. Пп. 8 ч. 1 вышеуказанной статьи закрепил обязанность недропользователя обеспечивать приведение участков земель и других природных объектов и ресурсов, при наличии нарушений, в состояние, которое пригодно для дальнейшего использования. Но, приведение их в состояние, которое пригодно для использования, и рекультивацию следует считать разными мероприятиями по охране земель. Следовательно, Положение о государственном контроле должно возлагать на государство обязанность 
DOI: 10.7256/1811-9018.2015.9.16159

При цитировании этой статьи сноска на доі обязательна

\section{Право и политика 9 (189) • 2015}

осуществления контроля за выполнением требований законодательства об обязанностях по приведению земель сельскохозяйственного назначения в то состояние, которое пригодно для использования по основному назначению (пп. «в» П. 3 Положения).

«Кодекс Российской Федерации об административных правонарушениях» от 30.12.2001 N 195-Ф3 (ред. от 02.05.2015) [7] предусматривает два состава административных правонарушений: ст. 8.7 «Невыполнение обязанностей по рекультивации земель, обязательных мероприятий по улучшению земель и охране почв» и ст. 8.8 - «Использование земельных участков не по целевому назначению, невыполнение обязанностей по приведению земель в состояние, пригодное для использования по целевому назначению».

Рекультивация земель урегулирована следующим образом. В соответствии со ст. 11 Закона РФ «О недрах» предоставление участка для ведения работ, которые связаны с геологическим изучением и иным использованием, осуществляется в установленном законодательством Российской Федерации порядке после утверждения проекта указанных работ (технического проекта). В данном случае необходимо наличие только технического проекта. Наличие утвержденного проекта рекультивации земель при этом не требуется. В соответствии с п. 10 ч. 1 ст. 12 Закона РФ «О недрах» лицензия и ее составные части содержат порядок и сроки составления проектов ликвидации и консервации горных выработок, а также рекультивации земель. Из диспозиции данной нормы вытекает, что проект рекультивации должен разрабатываться, только если началась процедура ликвидации или консервации горных выработок. Ст. 23.2 этого же закона говорит, что разработка месторождений и пользование недрами в целях, которые не связаны с добычей полезных ископаемых, должна осуществляться в соответствии с техническими проектами. Постановление Правительства РФ от 03.03.2010 N 118 (ред. от 26.12.2014) «Об утверждении Положения о подготовке, согласовании и утверждении технических проектов разработки месторождений полезных ископаемых и иной проектной документации на выполнение работ, связанных с пользованием участками недр, по видам полезных ископаемых и видам пользования недрами» [8] содержит требования к содержанию подобного рода проектной документации. В нее должны входить информация о сроках и условиях работ по консервации и ликвидации горных выработок, а также рекультивации земель. Отсюда можно сделать вывод, что в технические проекты включаются и условия работ по рекультивации земель. В дальнейшем это положение детализируются в актах более низкой юридической силы.

Действующее законодательство прямо не предусматривает обязанность разработки технического и специального проектов по рекультивации земель, что предусматривается земельным законодательством. Срок разработки технического проекта и проекта рекультивации, как правило, не совпадают. Тем не менее, технический проект предусматривает использование технологий проведения горных работ, имеющих возможность в дальнейшем препятствовать работам по рекультивации, что и происходит. Проект рекультивации разрабатывается после разработки месторождения тогда, когда необходимо ликвидировать и консервировать горные выработки. Рекультивация нарушенных земель как проблема встает, в том числе, и при добыче общераспространенных полезных ископаемых, на которых действует особые правила предоставления горных отводов. В соответствии со ст. 18 Закона РФ «О недрах» правила предоставления горных отводов для разработки месторождений полезных ископаемых общего распространения, правила пользования недрами физическими и юридическими лицами в границах земельных участков с целью добычи данных ископаемых, а также, если это не связано с добычей полезных ископаемых, определяются законами и иными актами субъектов РФ. Исследование законодательства субъектов РФ говорит о том, что в ряде случаев предусматривается рекультивация земель при добыче полезных ископаемых общего распространения, в других - нет. Например, в соответствии со ст. 16.1 Закона Ленинградской области «О порядке предоставления недр для разработки месторождений общераспространенных полезных ископаемых на территории Ленинградской области» [9] существенными условиями, невыполнение которых может повлечь прекращение действия лицензии, являются порядок и сроки разработки проектов ликвидации и консервации горных выработок, а также рекультивации земель.

Другая ситуация имеет место в Законе Московской области «О порядке предоставления права пользования участками недр, содержащими месторождения общераспространенных полезных ископаемых, или участками недр местного значения» [10], где не предусматривается необходимость рекультивации.

В соответствии со ст. 19.1 Закона РФ «О недрах» пользователи, главной целью деятельности которых является разведка и добыча полезных ископаемых и геологическое изучение, в границах предоставленных горных отводов и геологических отводов имеют 
возможность для собственных нужд осуществлять добычу полезных ископаемых общедоступного назначения в порядке, который устанавливается органами исполнительной власти субъектов РФ. В ряде случаев предусмотрено требование о рекультивации, в остальных - оно отсутствует. Итак, в законодательстве субъектов РФ есть различия в отношении регулирования данного вопроса. Но, независимо от того, предусмотрено оно в законодательстве субъектов РФ или нет, применяются нормы Закона РФ «О недрах», которые касаются регулирования рекультивации при разработке месторождений полезных ископаемых. В этой связи целесообразно закрепить в ст. 22 Закона РФ «О недрах» обязанность недропользователя проводить работы по рекультивации земель.

Также предлагается указать в ст. 11 Закона РФ «О недрах» о том, что земельный участок, предоставляемый для проведения работ по геологическому изучению и другим видам использования недр, должен осуществляться в порядке, который устанавливается земельным законодательством РФ, после утверждения и принятия технического проекта и проекта рекультивации. П. 10 ч. 1 ст. 12 Закона РФ «О недрах» должен предусматривать лицензию, которая должна содержать условия рекультивации в процессе пользования недрами, при ликвидации горных выработок, которые предусмотрены проектом рекультивации.

Также имеют место особенности правового регулирования рекультивации при проведении строительных работ. В соответствии с п. 3 ст. 37 ФЗ «Об охране окружающей среды» осуществление строительства и реконструкции зданий, строений и сооружений осуществляется вместе с мерами по охране окружающей природной среды, восстановлению окружающей природной среды, а также рекультивации земель. В п. 2 ст. 38 указанного Закона вводится запрет на ввод в эксплуатацию объектов без окончания работ по рекультивации. Требования по рекультивации, помимо этого, предусмотрены в п. 2 ст. 39 данного Закона. Общие требования законодательства об охране окружающей природной среды сводятся к случаям строительства зданий, строений и сооружений, ввода их в эксплуатацию, где требуется самостоятельный проект рекультивации земель сельскохозяйственного назначения. Тем не менее, в градостроительном законодательстве предусмотрен иной порядок составления проектной документации, не в полной мере соответствующий указанным нормам законодательства об охране окружающей природной среды. Требования, касающиеся архитектурно-строительного проекти- рования, сформулированы в ст. 48 ГрК РФ. Пункт 12 указанной статьи определяет состав документации объектов строительства, за исключением документации линейных объектов. В том числе, должен быть предусмотрен раздел с указанием перечня мероприятий по охране окружающей природной среды. В соответствии с Постановлением Правительства РФ от 16.02.2008 N 87 (ред. от 26.03.2014) «О составе разделов проектной документации и требованиях к их содержанию» [11] в разделе 8 «Перечень мероприятий по охране окружающей среды» должен содержаться перечень мероприятий по рекультивации земельных участков сельскохозяйственного назначения и почвенного покрова.

Итак, градостроительное законодательство не предусматривает разработки проектов рекультивации земель сельскохозяйственного назначения при строительстве объектов строительства. Рекультивационные мероприятия должны предусматриваться в проектной документации объектов строительства. И поэтому необходимо дополнить п. 3 ст. 51 ГрК РФ положением о недопущении выдачи разрешений на строительство без наличия утвержденного проекта рекультивации. В соответствии со ст. 43 Ф3 «Об охране окружающей среды» при осуществлении мелиорации земель сельскохозяйственного назначения должны приниматься меры по охране объектов природы, а также предупреждению любого иного негативного воздействия на окружающую природную среду при ведении мелиоративных мероприятий. В соответствии со ст. 2 Федерального закона от 10.01.1996 N 4-ФЗ (ред. от 31.12.2014) «О мелиорации земель» [12] мелиоративные мероприятия - это проектирование, строительство, эксплуатация и реконструкция мелиоративных систем и отдельно расположенных гидротехнических сооружений, обводнение пастбищ, создание систем защитных лесных насаждений, проведение культуртехнических работ, работ по улучшению химических и физических свойств почв, научное и производственно-техническое обеспечение указанных работ. Схожее определение дается в ст. 1 Федерального закона от 16.07.1998 N 101-Ф3 (ред. от 28.12.2013) «О государственном регулировании обеспечения плодородия земель сельскохозяйственного назначения» [13]. Из смысла данных норм права следует, что мелиоративные работы могут повлечь нарушение земель сельскохозяйственного назначения и, как следствие, необходимость их рекультивации. По правилам ст. 25 Ф3 «О мелиорации земель» мелиорация должна проводиться на основании проектов, которые разработаны в соответствии с различными обоснованиями при учете строительных, экологи- 


\section{Право и политика 9 (189) 2015}

ческих, санитарных и иных стандартов, норм и правил. В Инструкции о порядке разработки, согласования, утверждения и составе проектной документации на строительство объектов мелиорации земель [14] определяется состав проектной документации при строительстве объектов мелиорации земель сельскохозяйственного назначения. Например, проект на строительство объектов мелиорации должен предусматривать мероприятия по рациональному использованию и охране земельных участков. В том числе, к ним относятся рекультивация земель, нарушаемых при осуществлении мелиоративных мероприятий, устройстве карьеров и т.д.; площадь нарушаемых земель; объем плодородного грунта, подлежащий снятию и транспортировке (п. 7.2.2).

Цели, которые преследует мелиорация, сформулированы в ст. 1 Ф3 «О мелиорации земель». Основная цель - это повышение продуктивности и устойчивости земельного дела, обеспечение гарантированного производства сельскохозяйственных товаров на началах сохранения и повышения плодородия, а также создание условий для вовлечения в сельскохозяйственную деятельность неиспользуемых и малопродуктивных земель, а также формирование рациональной структуры земельных пашен и угодий. Мелиорация - это коренное улучшение земель сельскохозяйственного назначения, в которые входят гидротехнические, культуртехнические, химические, противоэрозионные, агролесомелиоративные, агротехнические и другие мелиоративные мероприятия (ст. 2 Ф3 «О мелиорации земель»).

Итак, одной из основных целей мелиорации земель сельскохозяйственного назначения является обеспечение охраны земель. Поэтому считаем нецелесообразным разработку самостоятельных проектов рекультивации земель сельскохозяйственного назначения при проведении мелиорации. Рекультивация земель сельскохозяйственного назначения должна быть предусмотрена в проектах мелиорации.

Следует обратить внимания на вопрос о рекультивации земель сельскохозяйственного назначения при осуществлении лесозаготовительных работ. В соот- ветствии с п. 1 ст. 29 ЛК РФ заготовка древесины - это предпринимательская деятельность, которая связана с рубкой лесных насаждений при их трелевке, частичной переработке, хранении и вывозом из леса древесины. Физические и юридические лица вправе в этих целях строить лесные дороги, лесные склады, другие строения и сооружения (п. 7 ст. 29 ЛК РФ).

Современный уровень проведения лесозаготовительных работ неизбежно приводит к нарушению почвенного покрова, что предопределяет необходимость рекультивации. Тем не менее, ЛК РФ содержит нормы, требующие проведение рекультивации только в определенных случаях. К примеру, в соответствии со ст. 13 ЛК РФ создание лесной инфраструктуры допускается в целях использования, охраны и воспроизводства лесов. Лесная инфраструктура подлежит сносу при достижении основной цели, а земли - рекультивации. Земельные участки по п. 6 ст. 21 ЛК РФ, используемые в целях строительства, реконструкции и эксплуатации объектов также подлежат рекультивации.

В соответствии с п.П. «г» П. 8 Правил заготовки древесины [15] заготовка древесины требует сноса построек и сооружений, а также рекультивацию земель, занятых ими, в течение шести месяцев по окончании вывоза древесины. Работы, направленные по заготовку древесины, должны осуществляться по правилам технологической карты разработки лесосеки, составляемой перед началом ее разработки (п. 52 Правил).

Требование законодательства о рекультивации касается тех лесных участков, которые имеют возведенные постройки и сооружения, но не лесосеки, которые пройдены рубками. Рекультивация земель, нарушенных рубкой лесных насаждений, частичной переработки и вывоза древесины, не требуется. Следует отметить также, что в Основных положениях по лесовосстановлению и лесоразведению в лесном фонде Российской Федерации [16], предусматривается, что применяемые технологии лесозаготовления должны предусматривать наибольшее сохранение леса и скорейшее накопление нового леса из ценных пород.

\section{Библиография:}

1. Постановление Правительства РФ от 23.02.1994 N 140 «О рекультивации земель, снятии, сохранении и рациональном использовании плодородного слоя почвы» // «Собрание актов Президента и Правительства РФ», 07.03.1994, N 10, ст. 779.

2. Приказ Минприроды РФ N 525, Роскомзема N 67 от 22.12.1995 «Об утверждении Основных положений о рекультивации земель, снятии, сохранении и рациональном использовании плодородного слоя почвы» (Зарегистрировано в Минюсте РФ 29.07.1996 N 1136) // «Бюллетень нормативных актов федеральных органов исполнительной власти», N 4, 1996.

3. Закон РФ от 21.02.1992 N 2395-1 (ред. от 31.12.2014) «О недрах» // «Собрание законодательства РФ», 06.03.1995, N 10, ст. 823.

4. Постановление Главного государственного санитарного врача РФ от 17.04.2003 N 53 (ред. от 25.04.2007) «О введении в действие СанПиН 2.1.7.1287-03» (вместе с «СанПиН 2.1.7.1287-03. 2.1.7. Почва, очистка населенных мест, бытовые 
DOI: $10.7256 / 1811-9018.2015 .9 .16159$

При цитировании этой статьи сноска на dоі обязательна

Правоведение

и промышленные отходы, санитарная охрана почвы. Санитарно-эпидемиологические требования к качеству почвы. Санитарно-эпидемиологические правила и нормативы», утв. Главным государственным санитарным врачом РФ 16.04.2003) (Зарегистрировано в Минюсте РФ 05.05.2003 N 4500) // «Бюллетень нормативных актов федеральных органов исполнительной власти», N 29, 21.07.2003.

5. Приказ Росстата от 29.12.2012 N 676 «Об утверждении статистического инструментария для организации Федеральной службой по надзору в сфере природопользования федерального статистического наблюдения за рекультивацией земель, снятием и использованием плодородного слоя почвы» // Документ опубликован не был.

6. Постановление Правительства РФ от 02.01.2015 N 1 «Об утверждении Положения о государственном земельном надзоре» // «Собрание законодательства РФ», N 2, 12.01.2015, ст. 514.

7. «Кодекс Российской Федерации об административных правонарушениях» от 30.12.2001 N 195-Ф3 (ред. от 02.05.2015) // «Собрание законодательства РФ», 07.01.2002, N 1 (ч. 1), ст. 1.

8. П Постановление Правительства РФ от 03.03.2010 N 118 (ред. от 26.12.2014) «Об утверждении Положения о подготовке, согласовании и утверждении технических проектов разработки месторождений полезных ископаемых и иной проектной документации на выполнение работ, связанных с пользованием участками недр, по видам полезных ископаемых и видам пользования недрами» // «Собрание законодательства РФ», 08.03.2010, N 10, ст. 1100.

9. Закон Ленинградской области от 30 мая 2000 г. N 13-О3 «О порядке предоставления недр для разработки месторождений общераспространенных полезных ископаемых на территории Ленинградской области» // Вестник Законодательного собрания Ленинградской области. 2000. N 4(47).

10. Закон Московской области от 10 апреля 2009 г. N 29/2009-О3 «О порядке предоставления права пользования участками недр, содержащими месторождения общераспространенных полезных ископаемых, или участками недр местного значения» // Ежедневные новости. Подмосковье. 2009. N 76.

11. Постановление Правительства РФ от 16.02.2008 N 87 (ред. от 26.03.2014) «О составе разделов проектной документации и требованиях к их содержанию» // «Собрание законодательства РФ» от 25 февраля 2008 г. N 8 ст. 744.

12. Федеральный закон от 10.01.1996 N 4-Ф3 (ред. от 31.12.2014) «О мелиорации земель» // «Собрание законодательства РФ», 15.01.1996, N 3, ст. 142.

13. Федеральный закон от 16.07.1998 N 101-Ф3 (ред. от 28.12.2013) «О государственном регулировании обеспечения плодородия земель сельскохозяйственного назначения» // «Собрание законодательства РФ», 20.07.1998, N 29, ст. 3399.

14. Инструкция о порядке разработки, согласования, утверждения и составе проектной документации на строительство объектов мелиорации земель. РД-АПК 3.00.01.002-02. Утв. Минсельхозом России 04.10.2002 (вместе с указаниями по составлению сводных расчетов стоимости строительства объектов мелиорации земель, Порядком определения затрат по главам 1 и 9-12 сводного сметного расчета) // СПС «КонсультантПлюс».

15. Приказ МПР России от 16 июля 2007 г. N 184 «Об утверждении Правил заготовки древесины» (зарегистрировано в Минюсте России 22 октября 2007 г. N 10374) // БНА ФОИВ. 2007. N 48.

16. Основные положения по лесовосстановлению и лесоразведению в лесном фонде Российской Федерации. Утв. Приказом Рослесхоза от 27 декабря 1993 г. N 344 // СПС «КонсультантПлюс». 